\title{
Pengaruh Penayangan Iklan Daring Selama Pandemi Covid-19 Terhadap Kognisi Konsumen Akan Kebutuhan Dan Perilaku
}

\author{
Konsumen \\ Cynthia, Sherly, Fidelius Marlfel, Marlyn, Keni Keni \\ Cynthia.115180395@stu.untar.ac.id,sherly.115180416@stu.untar.ac.id, \\ fidelius.115190434@stu.untar.ac.id,marlyn.615180082@stu.untar.ac.id,keni@fe..untar.ac.id \\ Program Studi Sarjana Manajemen, Fakultas Ekonomi dan Bisnis Universitas Tarumanagara Jakarta, \\ Program Studi Sarjana Desain Interior, Fakultas Seni Rupa dan Desain Universitas Tarumanagara \\ Jakarta, Program Studi Magister Manajemen, Universitas Tarumanagara Jakarta
}

\begin{abstract}
Online ads which are basically faster, more effective, and more accurate tend to be more engaging than traditional ads. The influence of online ads does not happen instantly, other factors contribute to the changes in consumer behavior to become more impulsive. Consumer need for cognition is the factor that mediates the relationship. Consumers who have need for cognition tend to be more easily influenced by online ads, especially when it's done repeatedly. Therefore, this study was conducted to examine the relationship between repeated online ads and consumer need for cognition for the changes in consumer behavior that was strengthened or weakened by the COVID-19 pandemic. Hypothesis testing was carried out by using Partial Least Square - Structural Equation Modeling (PLS-SEM) analysis with SmartPLS software. The research results showed that repeated online ads and consumers' need for cognition had a positive influence on consumer buying behavior, but the COVID-19 pandemic had a negative effect.
\end{abstract}

Keywords: consumer buying behavior, consumers' need for cognition, online ads, pandemic COVID-19.

\begin{abstract}
Abstrak
Iklan daring yang pada dasarnya lebih cepat, efektif, dan akurat cenderung lebih diminati dari pada iklan tradisional. Namun, pengaruh iklan daring tersebut tidak semata-mata terjadi begitu saja, melainkan ada faktor lain yang ikut andil dalam perubahan perilaku konsumen yang lebih impulsif, Kognisi konsumen akan kebutuhan adalah faktor yang menjadi perantara hubungan tersebut. Konsumen yang memiliki kognisi rendah cenderung lebih mudah terpengaruh dengan adanya penayangan iklan daring terutama jika dilakukan secara berulang. Oleh karena itu, penelitian ini dibuat dengan tujuan untuk menguji hubungan iklan daring secara berulang dan kognisi konsumen akan kebutuhan terhadap perubahan perilaku konsumen yang diperkuat atau diperlemah dengan adanya pandemi COVID-19. Pengujian hipotesis dilakukan dengan analisis Partial Least Square - Structural Equation Modeling (PLS-SEM) dengan software SmartPLS. Hasil penelitian menunjukkan bahwa penayangan iklan daring secara berulang dan kognisi konsumen berpengaruh positif kepada perubahan perilaku pembelian konsumen, namun pandemic COVID-19 memiliki pengaruh negatif.
\end{abstract}

Kata Kunci: iklan daring, kognisi konsumen akan kebutuhan, pandemi COVID-19, perilaku pembelian konsumen 


\section{Pendahuluan}

Pandemi COVID-19 menjadi sebuah tantangan baru yang akhir-akhir ini muncul baik bagi pemerintah maupun bisnis. COVID-19 membawa banyak masalah fisik dan mental yang mengakibatkan ketakutan dan stress selama berada di luar rumah (Naeem, 2021), terlebih ketika masyarakat mengalami penurunan gaji dan pemutusan hubungan kerja akibat pandemi (Keni \& Sandra, 2021). Akibat permasalahan ini, pemerintah langsung bertindak dan menerapkan Pembatasan Sosial Berskala Besar (PSBB) untuk meminimalisir penularan COVID-19, sehingga menyebabkan adanya penurunan interaksi sosial yang berdampak pada peningkatan intensitas konsumen dalam menggunakan media sosial hingga meningkatkan jumlah belanja melalui media sosial yang juga dikenal sebagai social commerce (Maria, Wijaya \& Keni, 2021). Perubahan tersebut merupakan salah satu bukti dari perkembangan dunia digitalisasi.

Di dalam dunia digitalisasi yang semakin pesat ini, muncul sarana dan prasarana baru yang dapat mempengaruhi perilaku pembelian konsumen. Salah satu hasil dari perkembangan digitalisasi ini ditunjukkan melalui adanya iklan secara daring. Gambar 1. membuktikan bahwa penggunaan iklan daring akan meningkat semakin pesat di masa yang akan datang. Jika dibandingkan dengan iklan tradisional secara luring, iklan daring memiliki keunggulan, dimana perolehan informasi konsumen semakin cepat dan karena menggunakan jaringan teknologi dapat memberikan cakupan yang lebih luas, cepat, efektif, dan akurat dalam menargetkan konsumen (Gong, Wang \& Li, 2019). Karena perbedaan tersebut, iklan daring memberi dampak terhadap perilaku pembelian konsumen. Perilaku pembelian konsumen mengacu kepada proses pencarian, pemilihan, pembelian, pemakaian, dan pengevaluasian suatu produk atau jasa dalam memenuhi kebutuhan dan keinginan konsumen (Ilmu Ekonomi ID, 2017).

Gambar 1. Infografis Tren Pasar Periklanan Digital Indonesia Tahun 2019

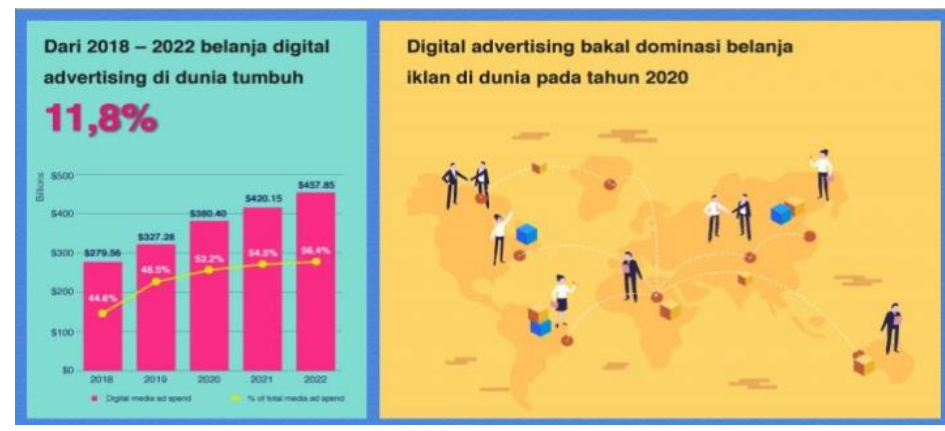

Sumber: Techfor Id (2019)

Iklan daring tidak semata-mata memberikan dampak langsung pada perilaku pembelian konsumen. Adanya kognisi konsumen akan kebutuhan menjadi perantara kedua faktor ini. kognisi inilah yang menjadi stimulus bagi konsumen di dalam melakukan pembelian. Dengan melihat iklan daring secara berulang, konsumen yang awalnya merasa tidak memerlukan suatu barang atau jasa akan terdorong dalam mengkognisikan kegunaan dan kebutuhan akan barang atau jasa tersebut. 
Tujuan dari penelitian ini adalah untuk mengetahui pengaruh penayangan iklan daring secara berulang pada perubahan perilaku pembelian konsumen melalui kognisi konsumen akan kebutuhan yang diperkuat atau diperlemah oleh pandemi COVID-19. Adanya perbedaan variabel dan adanya pengaruh pandemi COVID-19 membuat penelitian ini berbeda dari penelitian sebelumnya. Hasil penelitian ini diharapkan dapat dimanfaatkan pihak pemasar yang sedang mempertimbangkan untuk menggunakan iklan daring sebagai sarana untuk menarik konsumen dalam meningkatkan pembelian konsumen di masa pandemi COVID-19. Selain itu juga dapat meningkatkan kesadaran pemasar akan pentingnya iklan daring sebagai salah satu strategi komunikasi dalam meningkatkan pembelian yang memberikan keuntungan atau laba bagi perusahaan. Penelitian ini juga diharapkan dapat dimanfaatkan oleh peneliti lain untuk menjadi referensi penelitian lain berhubungan dengan pemasaran melalui penggunaan iklan daring di masa pandemi COVID-19 terhadap perilaku pembelian konsumen.

\section{Telaah Kepustakaan}

\section{Iklan daring secara berulang}

Menurut Ching et al. (2013), dengan adanya iklan daring bisa menimbulkan suasana hati yang positif yang dapat dicapai melalui teknologi antarmuka konsumen yang mendorong suasana hati positif konsumen melalui stimulasi audio dan visual. Iklan berbasis internet berbeda dengan iklan dalam media tradisional dikarenakan platform dalam internet mempunyai kemampuan teknologi yang mendukung keunikan dari fitur tersebut, termasuk adanya hubungan antara elemen stimuli dan aspek penghibur, untuk mengikat konsumen dan mempengaruhi pemikiran mereka.

Konsumen juga mempunyai kendali yang belum pernah ada dalam pengalaman mereka menonton iklan sebelumnya, yaitu dalam hal apa yang mereka lihat, bagaimana mereka melihatnya, berapa lama mereka melihatnya, dan bahkan kemampuan mereka dalam memodifikasi cerita dalam iklan tersebut (Gong, Wang \& Li, 2019). Dengan begitu, penayangan iklan daring secara berulang dapat menarik perhatian konsumen dan berpengaruh pada sikap terhadap suatu brand yang ditampilkan pada iklan daring tersebut (Hussain, Ferdous \& Mort, 2018).

\section{Kognisi konsumen akan kebutuhan}

Kognisi konsumen akan kebutuhan adalah kecenderungan setiap individu dalam memproses suatu informasi yang memerlukan pemikiran secara kognitif. Dengan adanya stimulus yang memicu ingatan atau pembelajaran seseorang yang pernah tertanam di ingatan jangka panjang, sehingga menghasilkan rasa ketertarikan dan rasa membutuhkan akan suatu barang atau jasa (Raziq et al., 2018).

\section{Perilaku pembelian konsumen}

Perilaku pembelian konsumen mengacu pada penelusuran konsumen terhadap barang atau jasa untuk memenuhi kebutuhannya (Amoako, Dzogbenuku \& Abubakari, 
2020). Penelusuran ini berujung dengan timbulnya dorongan dalam diri seseorang untuk melakukan pembelian barang atau jasa tersebut.

\section{Kaitan antara iklan daring secara berulang dengan kognisi konsumen akan kebutuhan}

Menurut Aqsa (2017) kognisi adalah cara setiap orang dalam melihat atau menggambarkan sesuatu. Hansen, Lee \& Lee (2014) menyatakan, bahwa seorang konsumen dengan kognisi yang tinggi akan berfikir secara intrinsik. Oleh karena itu, dengan pemaparan iklan dengan informasi yang kuat dan dilakukan secara berulang dapat menimbulkan pemikiran kognitif yang positif terhadap iklan dan brand tersebut.

Melalui iklan daring, konsumen mendapatkan informasi dan juga dapat menanggapi tayangan iklan daring, yang kemudian diolah sehingga timbul pemikiran akan kebutuhan suatu barang atau jasa yang diiklankan. Berdasarkan uraian di atas, maka hipotesis penelitian pertama adalah:

H1: Semakin sering penayangan iklan daring secara berulang, semakin tinggi pengaruhnya terhadap kognisi konsumen akan kebutuhan.

\section{Kaitan antara kognisi konsumen akan kebutuhan dengan perilaku pembelian konsumen}

Kognisi konsumen akan kebutuhan suatu barang atau jasa sangat berpengaruh terhadap perubahan perilaku pembelian mereka (Hume \& Mills, 2013). Perubahan tersebut dapat terjadi karena adanya faktor-faktor pemikiran kognitif seperti fungsionalitas produk, desain, garansi pasca-pembelian, loyalitas toko, dan hubungan konsumen-penjual (Graham \& Wilder, 2020). Menurut penelitian Sofi, Mir \& Baba (2020) menyatakan bahwa kognisi dapat mempengaruhi perilaku pembelian seorang individu. Dimana dengan tingkatan kognisi tertentu, seorang konsumen yang tadinya tidak memiliki perilaku pembelian impulsif akan cenderung melakukan pembelian secara impulsif. Berdasarkan uraian di atas, maka hipotesis penelitian kedua adalah:

H2: Semakin tinggi kognisi konsumen akan kebutuhan, semakin rendah pengaruhnya terhadap perilaku pembelian konsumen

\section{Kaitan antara iklan daring secara berulang dengan perilaku pembelian konsumen}

Menurut Aragoncillo dan Orús (2018), diakui bahwa dengan sistem yang lebih modern, intensitas pembelian menjadi lebih sering terjadi karena inovasi seperti kartu kredit, iklan daring, dan belanja di rumah memberikan kemudahan dalam memilih produk. Sebanyak $65 \%$ pengguna sosial media menegaskan bahwa iklan daring yang ditunjukkan dalam sosial media mempengaruhi proses pembelian mereka dan sekitar $45 \%$ pengguna sosial media dari riset yang sama mengatakan bahwa iklan daring dalam sosial media yang menjadi inspirasi dalam pembelian online mereka.

Dari peneliti sebelumnya, dapat kami ketahui bahwa konsumen dipengaruhi oleh tayangan iklan daring secara berulang. Karena iklan daring dalam media sosial dapat 
menjadi alat yang ampuh untuk meningkatkan perilaku pembelian konsumen. Berdasarkan uraian di atas, maka hipotesis penelitian ketiga adalah

H3: Semakin sering penayangan iklan daring secara berulang, semakin tinggi pengaruhnya terhadap perilaku pembelian konsumen

\section{Pandemi COVID-19 memoderasi kognisi konsumen akan kebutuhan terhadap perilaku pembelian konsumen}

Berdasarkan pada situasi pandemi COVID-19 ini memunculkan ketakutan pada masyarakat, karena munculnya ketakutan ini mendorong rasa emosional pelanggan dalam membeli produk ekstra (tambahan) bahkan di dalam keadaan yang tidak pasti ini. Meskipun pada studi sebelumnya mengungkapkan bahwa konsumen menghindari pembelian di situasi yang tidak pasti, ketakutan akan suatu penyakit, dan kekhawatiran akan ketersediaan barang yang terbatas, dapat menimbulkan kepanikan di dalam perilaku pembelian.

Penelitian menemukan bahwa para konsumen bersikap rasional dalam membeli produk yang diperlukan, namun karena adanya pemahaman yang terbatas akan mengapa ketakutan ini terjadi dan apa resikonya, mengubah keputusan pembelian mereka di masa yang tidak pasti karena rasa ketakutan mereka pada saat pandemi COVID-19 ini (Naeem, 2021). Berdasarkan uraian di atas, maka hipotesis penelitian kelima adalah

H4: Pandemi COVID-19 akan memperkuat pengaruh kognisi konsumen akan kebutuhan terhadap perilaku pembelian konsumen

\section{Model Penelitian}

Berdasarkan uraian yang dipaparkan, peneliti menemukan model penelitian sebagai berikut:

Gambar 2. Model Penelitian

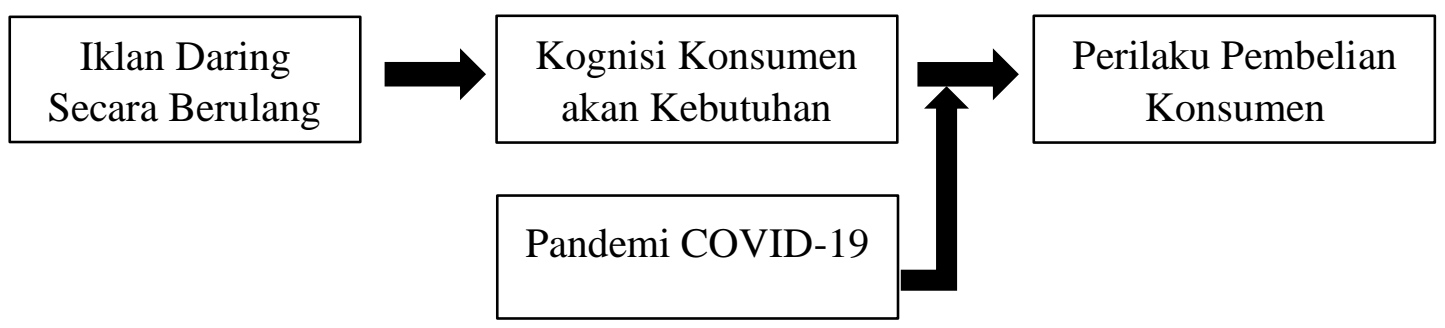

Sumber: Olahan Peneliti (2021)

\section{Metode Penelitian}

Penelitian ini menggunakan metode deskriptif dengan desain cross-sectional. Pengumpulan data dilakukan satu kali dalam kurun waktu 5 hari. Jenis data penelitian adalah data empirik yang menggunakan survei secara daring. Populasi ditargetkan kepada seluruh pengguna media daring. Pengambilan sampel menggunakan teknik 
non-probability sampling pada 244 responden dengan menggunakan Google Form. Namun, data yang valid sebanyak 180 responden. Berdasarkan data yang dikumpulkan tersebut, mayoritas responden berjenis kelamin perempuan (64,3\%), berusia $17-20$ tahun $(57 \%)$, Pendidikan terakhir SMA/SMK (74,6\%), memiliki pekerjaan pelajar/mahasiswa $(83,2 \%)$, dan memiliki pengeluaran perbulan kurang dari Rp $3.000 .000(70,5 \%)$.

Skala pengukuran dalam penelitian ini yaitu Skala Likert dengan 5 poin, antara lain: 1 = Sangat Tidak Setuju, $2=$ Tidak Setuju, $3=$ Netral, $4=$ Setuju, $5=$ Sangat Setuju. Instrumen dalam penelitian mengacu pada tabel berikut ini. Teknik analisis data menggunakan bantuan perangkat lunak komputer Partial Least Square Structural Equation Modeling (PLS-SEM). Nilai signifikan $(\alpha)$ dalam penelitian ini menggunakan 5\% dan nilai t-statistics yang diperlukan adalah lebih dari 1,96 dengan nilai $p$-value lebih rendah dari 0,05 (Ringle et al., 2019).

Tabel 1. Instrumen Penelitian

\begin{tabular}{|c|c|c|c|}
\hline Item & Outer Loadings & AVE & Sumber \\
\hline $\begin{array}{l}\text { Menurut saya, iklan daring memberikan } \\
\text { informasi yang berharga (ROA 3) }\end{array}$ & 0,782 & \multirow[b]{2}{*}{0,724} & \multirow{2}{*}{$\begin{array}{c}\text { Pollay dan } \\
\text { Mittal (1983); } \\
\text { Hussain, } \\
\text { Ferdous, dan } \\
\text { Mort (2017) }\end{array}$} \\
\hline 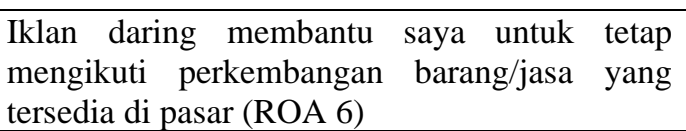 & 0,915 & & \\
\hline $\begin{array}{l}\text { Ketika menghadapi masalah baru, saya dapat } \\
\text { memikirkan solusi yang relevan (NFC 1) }\end{array}$ & 0,799 & \multirow{3}{*}{0,595} & \multirow{3}{*}{$\begin{array}{l}\text { Raziq et al. } \\
\quad(2018)\end{array}$} \\
\hline $\begin{array}{l}\text { Saya akan mengevaluasi pilihan saya sebelum } \\
\text { mengambil keputusan (NFC 3) }\end{array}$ & 0,752 & & \\
\hline $\begin{array}{l}\text { Saya akan mencari informasi terlebih dahulu } \\
\text { sebelum membeli barang/jasa (NFC 5) }\end{array}$ & 0,761 & & \\
\hline $\begin{array}{l}\text { Saya merasa aman saat berada di rumah saja } \\
(\mathrm{CO} 1)\end{array}$ & 0,782 & \multirow{3}{*}{0,641} & \multirow{3}{*}{$\begin{array}{l}\text { Alves, } \\
\text { Samorinha, } \\
\text { Precioso } \\
\text { (2020) }\end{array}$} \\
\hline $\begin{array}{l}\text { Saya khawatir keluarga atau teman saya tertular } \\
\text { virus COVID-19 (CO 3) }\end{array}$ & 0,824 & & \\
\hline $\begin{array}{l}\text { Karena COVID-19, saya membatasi } \\
\text { interaksi/kontak sosial secara langsung (CO 4) }\end{array}$ & 0,796 & & \\
\hline $\begin{array}{l}\text { Saya membeli barang/jasa untuk memenuhi } \\
\text { kebutuhan saya (CBB 2) }\end{array}$ & 0,884 & \multirow[b]{2}{*}{0,747} & \multirow{2}{*}{$\begin{array}{l}\text { Jain, Khan, } \\
\text { Mishra (2017) }\end{array}$} \\
\hline $\begin{array}{l}\text { Saya biasanya membeli barang/jasa sesuai } \\
\text { dengan kegunaannya (CBB } 4)\end{array}$ & 0,845 & & \\
\hline
\end{tabular}

Sumber: Olahan Peneliti (2021)

\section{Hasil Temuan dan Diskusi}

\section{Hasil Uji Statistik}

Dalam Melakukan penelitian ini digunakan uji validitas dan reliabilitas. analisis dilakukan untuk outer model dan inner model. Menurut Hair, Ringle, dan Sarstedt (2014) dalam melakukan penelitian harus dilakukan uji validitas dan reliabilitas agar konstruk pengukuran dalam outer model penelitian ini dapat diukur dan disajikan dengan baik. 
Menurut Kuppelwieser et al. (2014) "validitas diperiksa dengan memperhatikan validitas konvergen dan validitas diskriminan”. Dalam melakukan uji analisis validitas dilakukan pengujian validitas konvergen dan validitas diskriminan. Validitas Konvergen diukur dengan melihat nilai dari outer loadings dari setiap indikator dan juga nilai average variance extracted (AVE). Nilai dari validitas konvergen dianggap memenuhi jika nilai dari $\mathrm{AVE} \geq 0,5$ dan dengan nilai dari outer loadings setiap indikator > 0,7 (Hair et al., 2014). Berdasarkan hasil analisis dari outer loadings, terdapat sepuluh indikator dengan nilai > 0,7 dan sembilan indikator dengan nilai < 0,7 . Berdasarkan hasil analisis AVE, semua variabel memiliki nilai $\geq 0,5$, yang artinya memenuhi syarat (Tabel 1).

Hair et al. (2014) menyatakan bahwa discriminant validity dapat diukur dengan melakukan analisis fornell-larcker dengan memperhatikan nilai AVE dari setiap variabel harus lebih besar dari pada nilai korelasi kuadrat tertinggi antar variabel penelitian; dan nilai loadings dari indikator setiap variabel lebih besar dari crossloadings dalam variabel - variabel lainnya. Berdasarkan hasil analisis cross-loadings, setiap indikator memiliki nilai yang lebih besar dari indikator lainnya yang artinya memenuhi syarat. Sementara, dari analisis fornell-larcker, nilai AVE variabel lebih besar dari nilai korelasi kuadrat tertinggi antar variabel penelitian, yang artinya juga memenuhi syarat.

Tabel 2. Hasil Analisis Cross-Loading

\begin{tabular}{ccccc}
\hline Item & CBB & CO & NFC & ROA \\
\hline CBB2 & 0,884 & 0,273 & 0,392 & 0,393 \\
\hline CBB4 & 0,845 & 0,288 & 0,366 & 0,289 \\
\hline CO1 & 0,63 & 0,782 & 0,378 & 0,337 \\
\hline CO3 & 0,278 & 0,824 & 0,379 & 0,231 \\
\hline CO4 & 0,232 & 0,796 & 0,339 & 0,360 \\
\hline NFC1 & 0,350 & 0,324 & 0,799 & 0,412 \\
\hline NFC3 & 0,248 & 0,342 & 0,752 & 0,309 \\
\hline NFC5 & 0,394 & 0,392 & 0,761 & 0,375 \\
\hline ROA3 & 0,270 & 0,277 & 0,301 & 0,782 \\
\hline ROA6 & 0,390 & 0,363 & 0,488 & 0,915 \\
\hline
\end{tabular}

Sumber: Olahan Peneliti (2021)

Tabel 3. Hasil Analisis Fornell-Larcker

\begin{tabular}{ccccc}
\hline Variabel & CBB & CO & NFC & ROA \\
\hline CBB & 0,865 & & & \\
\hline CO & 0,323 & 0,801 & & \\
\hline NFC & 0,439 & 0,458 & 0,771 & \\
\hline ROA & 0,398 & 0,382 & 0,480 & 0,851 \\
\hline
\end{tabular}

Sumber: Olahan Peneliti (2021)

Menurut Peterson dan Kim (2013), analisis berikutnya yang harus dilakukan adalah analisis reliabilitas biasanya mean composite reliablity lebih tinggi dari mean Cronbach's Alpha, namun tidak memiliki perbedaan yang signifikan. Oleh karena itu, penentuan reliabilitas dapat dilihat dari salah satu mean tersebut karena tidak memiliki 
pengaruh besar dalam mengembangkan penelitian. Hasil analisis reliabilitas menyatakan bahwa composite reliablity semua variabel memiliki nilai diatas 0,7 yang artinya memenuhi syarat reliabilitas.

Tabel 4. Hasil Analisis Reliabilitas

\begin{tabular}{ccc}
\hline Variabel & Cronbach's Alpha & Composite Reliability \\
\hline Perilaku Pembelian Konsumen & 0,664 & 0,747 \\
\hline Pandemi COVID-19 & 0,721 & 0,641 \\
\hline Kognisi Konsumen akan Kebutuhan & 0,664 & 0,595 \\
\hline Penayangan Iklan Daring secara Berulang & 0,634 & 0,724 \\
\hline
\end{tabular}

Sumber: Olahan Peneliti (2021)

Berdasarkan Ringle et al. (2019), dalam penelitian formatif perlu dilakukan uji model struktural untuk mengetahui seberapa kuat hubungan antar variabel di dalam model dan untuk menguji hipotesis yang telah dirumuskan. Menurut Ringle et al. (2019), dalam uji R-square nilai sebesar 0,75; 0,50; 0,25 termasuk substansial, moderat, dan lemah. Pada nilai R-square variabel perubahan perilaku pembelian konsumen adalah sebesar $25,7 \%$ yang artinya lemah dan R-square pada variabel mediasi kognisi konsumen akan kebutuhan adalah 23,1\% yang artinya kemampuan variabel penayangan iklan daring secara berulang, kognisi konsumen akan kebutuhan, dan pandemic COVID-19 menjelaskan variabel perubahan perilaku pembelian konsumen lemah.

Menurut Ringle et al. (2019), nilai path coefficients digunakan untuk menilai tingakt signifikansi dan relevansi secara statistik. Dimana peneliti harus melakukan bootstrap untuk mengetahui nilai signifikansi path coefficients dan untuk mengevaluasi nilainya, dimana biasa nilai tersebut terletak di antara -1 hingga +1 . Peneliti juga dapat menginterpretasikan efek tidak langsung pada konstruk target tertentu melalui satu atau lebih konstruk intervensi. Efek ini sangat relevan dalam penilaian efek mediasi. Hubungan antara MO1 ke CBB adalah -0,106 terletak antara 0 dan -1 yang artinya hubungannya negatif. Sementara, hubungan NFC ke CBB adalah 0,292; hubungan ROA ke CBB adalah 0,238; dan hubungan ROA ke NFC adalah 0,480 yang terletak diantara 0 dan 1 yang artinya positif.

Tabel 5. Uji Boostrapping

\begin{tabular}{cccc}
\hline Keterangan & Path Coefficient & t-statistics & p-values \\
\hline CO -> CBB & 0,057 & 0,746 & 0,456 \\
\hline MO1 -> CBB & $-0,106$ & 1,581 & 0,114 \\
\hline NFC -> CBB & 0,292 & 3,568 & 0,000 \\
\hline ROA -> CBB & 0,238 & 3,727 & 0,000 \\
\hline ROA -> NFC & 0,480 & 7,411 & 0,000 \\
\hline
\end{tabular}

Sumber: Olahan Peneliti (2021)

Menurut Ringle et al. (2019), menyatakan bahwa dalam menilai uji hipotesis, dapat dilihat dari nilai $t$-statistic atau p-values melalui bootstrapping. Pengujian hipotesis dilakukan dengan membandingkan nilai dari t-statistic dengan batas 
minimum 1,96. Hipotesis penelitian tidak ditolak apabila nilai $t$-statistic $>1,96$ atau nilai $p$-values $<5 \%$ sedangkan hipotesis penelitian ditolak apabila nilai $t$-statistic < 1,96 atau $p$-values $>5 \%$. Pada Tabel 5., $\mathrm{H}_{1}, \mathrm{H}_{2}$, dan $\mathrm{H}_{3}$ tidak ditolak, sementara $\mathrm{H}_{4}$ ditolak. Yang artinya, variabel penayangan iklan daring secara berulang berpengaruh positif pada berubahan perilaku pembelian konsumen, variabel kognisi konsumen akan kebutuhan juga berpengaruh positif terhadap perubahan perilaku pembelian konsumen, variabel penayangan iklan daring secara berulang berpengaruh positif pada variabel kognisi konsumen akan kebutuhan, namun variabel pandemi COVID-19 malah memperlemah hubungan antara variabel kognisi konsumen akan kebutuhan dengan perubahan perilaku pembelian konsumen.

\section{Pembahasan}

Berdasarkan pengujian pada path-coefficient pada Tabel 5., dapat disimpulkan bahwa penayangan iklan daring secara berulang berpengaruh positif terhadap kognisi konsumen akan kebutuhan dengan path coefficient sebesar 0,480 sehingga terbukti bahwa hipotesis $\left(\mathrm{H}_{1}\right)$ diterima. Oleh karena itu, dengan pemaparan iklan dengan informasi yang kuat dan dilakukan secara berulang dapat menimbulkan pemikiran kognitif yang positif terhadap iklan dan brand tersebut.

Hasil pengujian hipotesis berikutnya $\left(\mathrm{H}_{2}\right)$, diperoleh bahwa kognisi konsumen akan kebutuhan berpengaruh positif terhadap perilaku pembelian konsumen dengan path coefficient sebesar 0,292 sehingga terbukti bahwa hipotesis $\left(\mathrm{H}_{2}\right)$ diterima. Hal ini sejalan dengan penelitian yang dilakukan oleh Sofi, Mir \& Baba (2020) menyatakan bahwa kognisi dapat mempengaruhi perilaku pembelian seorang individu. Dimana dengan tingkatan kognisi tertentu, seorang konsumen yang tadinya tidak memiliki perilaku pembelian impulsif akan cenderung melakukan pembelian secara impulsif.

Selanjutnya hasil pengujian hipotesis $\left(\mathrm{H}_{3}\right)$, diperoleh bahwa penayangan iklan daring secara berulang berpengaruh positif terhadap perilaku pembelian konsumen dengan path coefficient sebesar 0,238 sehingga terbukti bahwa hipotesis $\left(\mathrm{H}_{3}\right)$ diterima. Hal ini sejalan dengan penelitian yang dilakukan Aragoncillo dan Orús (2018) bahwa perilaku pembelian konsumen dipengaruhi oleh tayangan iklan daring secara berulang. Karena iklan daring dalam media sosial dapat menjadi alat yang ampuh untuk meningkatkan perilaku pembelian konsumen.

Lalu hasil pengujian hipotesis $\left(\mathrm{H}_{4}\right)$, diperoleh bahwa pandemi COVID-19 memperlemah hubungan antara kognisi konsumen akan kebutuhan dengan perilaku pembelian konsumen dengan path coefficient sebesar $-0,106$ sehingga hipotesis $\left(\mathrm{H}_{4}\right)$ ditolak

\section{Simpulan}

Berdasarkan hasil analisis yang telah dilakukan maka dapat disimpulkan bahwa pengaruh penayangan iklan daring secara berulang terhadap kognisi konsumen akan kebutuhan positif dan signifikan, pengaruh kognisi konsumen akan kebutuhan terhadap perilaku pembelian konsumen positif dan signifikan, pengaruh penayangan 
iklan daring secara berulang terhadap perilaku pembelian konsumen positif dan signifikan, dan pengaruh moderasi pandemi COVID-19 kognisi konsumen akan kebutuhan terhadap perilaku pembelian konsumen negatif dan tidak signifikan.

\section{Ucapan Terima Kasih}

Peneliti mengucapkan terima kasih kepada Kementerian Pendidikan dan Kebudayaan yang telah mengadakan acara dan memberikan hibah dana penelitian. Tidak lupa, kami juga mengucapkan terima kasih kepada pihak Universitas Tarumanagara, khususnya Jurusan Manajemen Fakultas Ekonomi dan Bisnis, yang telah memberikan kesempatan untuk mengikuti Program Kreativitas Mahasiswa (PKM) 2021. Terima kasih juga kami ucapkan kepada seluruh pihak yang telah terlibat dan membantu dalam proses pembuatan penelitian ini.

\section{Daftar Pustaka}

Alves, R, F., \& Samorinha, C. Precioso, J. (2020). Knowledge, attitudes and preventive behaviors toward COVID-19: a study among higher education students in Portugas. Journal of Health Research.

Amoako, G, K., \& Dzogbenuku, R, K. Abubakari, A. (2020). Do green knowledge and attitude influence the youth's green purchasing? Theory of planned behavior. International Journal of Productivity and Performance Management. 69(8), 1609-1629.

Ananda Pratiwi, S., \& Hidayat, D. (2020). Iklan layanan masyarakat Covid-19 di media sosial dan perilaku masyarakat di Jawa Barat.

Aqsa, M. (2017). Pengaruh iklan online terhadap sikap dan minat beli konsumen secara online di kota Palopo. Prosiding Seminar Nasional. 3(1), 82-93.

Aragoncillo, L., \& Orús, C. (2018). Impulse buying behaviour: an online-offline comparative and the impact of social media. Spanish Journal of Marketing. 22(1), 42-62.

Graham, K, W., \& Wilder. K.M. (2020). Consumer-brand identity and online advertising message elaboration: effect on attitudes, purchase intent and willingness to share. Journal of Research in Interactive. 14(1), 111-132.

Hansen, S, S., Lee, J, K., \& Lee, S, Y. (2014). Consumer-generated ads on youtube: impacts of source credibility and need for cognition on attitudes, interactive behaviours, and e-WOM. Journal of Electronic Commerce Research . 15(3), 254266.

Hume, M. Mills, M. (2013). Uncovering victoria's secret: exploring women's luxury perceptions of intimate apparel and purchasing behavior. Journal of Fashion Marketing and Management. 17(4), 460-485.

Hussain, R. Ferdous, A, S., \& Mort, G, S. (2018). Impact of web banner advertising frequency on attitude. Asia Pasific Journal of Marketing and Logistics. 30(2), 380-399.

Ilmu Ekonomi ID. (2017). Perilaku pembelian konsumen. URL:www.ilmu- ekonomiid.com. Diakses Tanggal 4 Maret 2021.

Jain, S., \& Khan, M, N. Mishra, S. (2017). Understanding consumer behavior regarding luxury fashion goods in India based on the theory of planned behavior. Journal of Asia Business Studies. 11(1), 4-21. 
Keni, K., \& Sandra, K. K. (2021). Prediksi customer experience dan service quality terhadap customer loyalty: customer satisfaction sebagai variabel mediasi. Jurnal Muara Ilmu Ekonomi dan Bisnis, 5(1), 191-204.

K.H Ching, R., \& Tong, P. Chen, J. Chen, H. (2013). Narrative online advertising: identification and its effects on attitude towards a product. Internet Research. 23(4), 414-438.

Li, Q. Gong, S., \& Wang, W. (2019). Marketing communication in the digital age: online ads. online WOM and mobile game adoptions. Nankai Business Review International. 10(3), 382-407.

Maria, I., Wijaya, V., \& Keni, K. (2021). Pengaruh information quality dan service quality terhadap perceived value dan konsekuensinya terhadap customer engagement behavior intention (Studi pada social commerce instagram). Jurnal Muara Ilmu Ekonomi dan Bisnis, 5(2), 321-334.

Naeem, M. (2021). Understanding the customer psychology of impulse buying during Covid-19 pandemic: implications for retailers. International Journal of Retail \& Distribution Management. 49(3), 377-393.

Peterson, R, A., \& Kim, Y. (2013). On the relationship between coefficient alpha and composite reliability. Journal of Applied Psychology. 98(1), 194-198.

Raziq, M, M., \& Ahmed, Q, M. Ahmad, M. Yusaf, S. Sajjad, A. Waheed, S. (2018). Advertising skepticism, need for cognition and consumers' attitudes. Marketing Intelligence \& Planning. 36(6), 678-693

Sofi, S, A., \& Mir, F, A. Baba, M, M. (2020). Cognition and affect in consumer decision making: conceptualization and validation of added constructs in modified instrument. Future Business Journal. 6(1), 31.

Techfor Id. (2019). Tahun 2019, Indonesia memiliki potensi yang pesat dalam dunia digital marketing. Retrieved Maret 04, 2021, From Techfor.id: www.techfor.id. 